\title{
A Contrastive Study on French and Urhobo Phonological Systems-A Case Study of Articles and Demonstrative Structures
}

\author{
Carole E. Okenrentie, Ph.D. \\ Delta State University, Abraka, Delta State, Nigeria
}

\begin{abstract}
It is a general knowledge that French as a language is widely spoken internationally whereas Urhobo is mainly spoken in the geographical location where it belongs. It is also spoken, and this, sparingly so, by Urhobo persons in the Diaspora. Presently, Urhobo has become a language of study at the Delta State University, Abraka. It has also been included in the educational curriculum for study at the lower cadre of secondary school education in the Delta State. This situation has triggered the author's interest in doing a contrastive phonological study. The significance of this study is that it will highlight the salient differences in some of the grammatical aspects in the languages under consideration and also identify the difficulties that learners experience as a result of these difficulties. The author will also, as much as it is possible, proffer solutions to these learning difficulties.
\end{abstract}

Keywords: contrastive, study, French, Urhobo, phonology, articles

\section{Introduction}

There may have been contrastive studies done on the phonological systems of French and other Nigerian languages or dialects before now but that of French and Urhobo phonology is comparatively new. Akpofure (2015) provides us with a thesis titled Une étude comparée des systèmes phonologiques du français et de l'urhobo. This book, which may not be the first to study this aspect of French and Urhobo phonology, although to the best of our knowledge, seems to be the only available work on the French/Urhobo theme just now treats the subject on hand. It will largely serve as our reference as this work progresses.

The Urhobo language is spoken in the Delta State of Nigeria as well as in the Diaspora. Odiemo (2014, p. 1) puts the number of Urhobo language speakers at about one million according to the 2006 census, a number which could possibly be contested due to possible lapses in the census exercise.

\section{Objective}

This study is aimed at exposing language students to the differences and similarities which exist in the phonological systems of French and Urhobo languages. It is expected that an understanding of these differences will facilitate learning either of the French or Urhobo language as the case may be. (Let it be noted in passing that Urhobo, like lots of African languages, is fast becoming a second or even third language to the owners.)

Carole E. Okenrentie, Ph.D., Department of Languages and Linguistics, Delta State University. 


\section{Theoretical Framework}

We will base this study on the Optimality Theory. Zuraw (2014, p. 3) cites Prince and Smolensky (1993, p. 1 ) as saying that this theory "...was developed as a response to a conceptual crisis at the center of phonological thought". He also goes on to say that "in a 1970 Linguistic Inquiry article, Charles Kisseberth identified a 'conspiracy' in Yawelmani: rules of vowel insertion and deletion conspire to place every consonant adjacent to a vowel".

\section{Methodology}

To fully treat this subject, the eclectic approach will be adopted since it is required that various technics be used to gather data for it. For example, there will be recordings that would help to determine the different sounds in both languages under consideration, verbal interviews, etc. This study will begin with the discussion of definite and indefinite articles. This will be followed by demonstrative structures. Under the demonstrative structures, we will treat adjectives and pronouns. Pluralization will invariably be treated in connection with all the areas under consideration since it is interwoven with articles, demonstrative adjectives, as well as demonstrative pronouns. The structure of this work is therefore as follows:

(1) The Article;

(2) The Demonstrative Adjectives (Determiners);

(3) The Demonstrative Pronouns;

(4) Phonological Processes;

(5) Conclusion.

As it is, the French aspect will be discussed in this work, not because we do not know what the elements to be treated in French are, but because it is what we know of these reference points in French that will enable us to highlight the differences between its phonological system and that of the Urhobo language.

\section{The Article}

For Trueman (2015, p. 1), "An article (...) is a word (or prefix or suffix) that is used with a noun to indicate the type of reference being made by the noun. Articles specify grammatical definiteness of the noun, in some languages extending to volume or numerical scope". Ade Ojo (2002) agrees with this definition when he states that:

Articles are the words used for presenting or identifying (the gender and number of) nouns, all the possessive pronouns and a few indefinite pronouns (like même, autre). Each noun is preceded immediately by the article, except when there is an intervening adjective before the noun. In which case the article is placed before such an adjective. (p. 58)

Mazet (2015, p. 1) affirms that "...French has definite articles, indefinite articles and partitive articles. The French definite article is the equivalent of the English the. But French has four forms of article défini...". Mazet goes on to name them as /le/, /la/, /l', and /les/. By this it is clearly affirmed that the French article has three different parts, i.e., the definite, the indefinite, and the partitive articles. This is different from the Urhobo situation where the article "na" has no parts other than one. Clearly the Urhobo article "na" is used to represent both the definite and the indefinite articles. As for the partitive article, this is not yet clearly represented in Urhobo phonology, although it will be more fully examined later on in this work.

\section{The Definite Article}

Ade Ojo (2002, p. 58) and Alden (1965, p. 197) also affirm that in French the definite article comprises of 
/le/, /la/, /l\%/, and /les/. /Le/ indicates the masculine noun as in (1) le père; (2) le gillet; and (3) le bidon. /La/ indicates feminine nouns as in: (1) la mère; (2) la famille; and (3) la maison. The /l'/ is used when the noun in question begins with a vowel and it does not distinguish between the masculine and the feminine. The elision of the vowel brings about a contraction. This contraction makes room for a free flow of the sequence between article and noun, creating in the process, a more fluid and pleasant form of articulation. For example, instead of (1) /Le enfant/ [ləãfã], one says [lãfã]; instead of (2)/la église/ [laegliz], one says /l'église/ [legliz].

The rule of vowel elision clearly applies here. Quite different from the case of the French article, this rule does not apply as touching the Urhobo article /na/. The Urhobo article "na" is the direct equivalent of the French definite articles $/ \mathrm{le} /, / \mathrm{la} /$, and $/ 1 \%$. Another difference between the French and the Urhobo article is that the Urhobo article 'na' does not come before the noun; it comes after it, as in:

Example: /ọ́mọ́ nà/ l’enfant. Ex : (ọ́mọ́/enfant, nà/l’)

$$
\begin{aligned}
& \text { /ọ́mọ́shārè nà - Le garçon } \\
& \text { /ọ́mōtẹ nà/ - la fille } \\
& \text { /ọ́shārè nà/ - l'homme } \\
& \text { /Aye nà/ - la femme. }
\end{aligned}
$$

(The examples above as well as some others that will follow are extracted from Akpofure (2015, p. 200), not for want of other examples to give, but to clearly indicate how the Urhobo article /nà/ is appropriately used for the masculine as well as the feminine gender. The reason is that apart from persons most of the other nouns are without gender distinction.) The examples noted above also show that whereas in the French language, the article comes before the noun (or before the adjective, as the case may be), clearly indicating the gender of the noun in question; the Urhobo article does not precede the noun, or the adjective (as the case may be) neither does it distinguish between masculine and feminine nouns. In most cases, it also comes after the adjective. The French "l"” has no equivalent in Urhobo. The article /nà/describes the masculine as well as feminine noun:

Example: /ọ́mọ́shārè nà = le garçon

$$
\begin{aligned}
& \text { /ọ́mōtẹ nà = la fille. } \\
& \text { /ọ́bé nà = le livre } \\
& \text { /ísīkúrù nà = l'école etc. }
\end{aligned}
$$

When the sentence features an adjective, the article still comes after the adjective:

Example: /ọ́shārè ógrógrò nà [ग\are ogrogro na] Le grand homme.

\section{Pluralization of the Definite Article}

The plural form of the French definite article /Les/ is used to represent both masculine and feminine genders.

$\begin{array}{lll}\text { Example: } & \text { Singular } & \text { Plural } \\ & \text { L'homme } & \text { Les hommes } \\ \text { La femme } & \text { Les femmes } \\ \text { Le garçon } & \text { Les garçons } \\ \text { La fille } & \text { Les filles }\end{array}$


This implies that the plural article/les/ does not distinguish between the masculine and feminine nouns. The determination of the gender therefore depends on the nature of the noun. The Urhobo plural form does not distinguish between the masculine and the feminine gender either. This therefore is a similarity in the plural articles of both languages. What happens in the case of the Urhobo article "nà" is that while "nà" remains, the initial vowel for the noun in its singular form modulates into a plural vowel as in the case of /o/ (singular form) changing to /e/ (plural form). This implies that it is the initial vowels of the nouns that show the effect of pluralization. This is what Oyiborhoro $(2005$, p. 77$)$ implies when he says that: "Pluralization in Urhobo is essentially achieved by replacing the vowel at the beginning of the word with another vowel and change from a singular prefix to a plural prefix". The singular prefixes are usually a, e, and i, depending on the nature of the word in question. The plural prefixes are generally e, $i$, and a. The following examples were extracted from Akpofure (op. cit., p. 200).

\begin{tabular}{|c|c|c|}
\hline \multirow[t]{7}{*}{ Example } & Singular & Plural \\
\hline & /ọ́mō nà/[omo na] l'enfant. & /émō na/ [emō nà] les enfants \\
\hline & /ọ́mọ́shārè nà [omภfare na] - Le g & on/éméshārè nà [emefare na] - Les garçons \\
\hline & 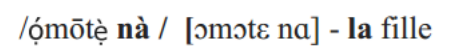 & /émētè nà/ [emet $\varepsilon$ na] - les filles \\
\hline & /ọ́shārè nà / [0 Jare na] - l'homme & /éshārè nà/ [efare na] - les hommes \\
\hline & /àyē nà/ [aye na] - la femme. & /éyā nà/ [eya na] - les femmes. \\
\hline & /éwūn nà/ [ewu] - La robe & /íwūn nà/ [iwu na] - les robes \\
\hline
\end{tabular}

\section{Indefinite Articles}

Ade Ojo (op. cit., p. 58) and Alden (op. cit., p. 197) affirm also that the indefinite articles in French grammar are: /un/, /une/, and /des/. /Un/ is the masculine singular article and /une/ the feminine singular article while /des/ indicates the plural nouns. The Urhobo equivalent of /un/ and /une/ is /ọvó/ [əvo].

\begin{tabular}{|c|c|c|}
\hline \multirow[t]{6}{*}{ Example: } & French & Urhobo \\
\hline & Un garçon & 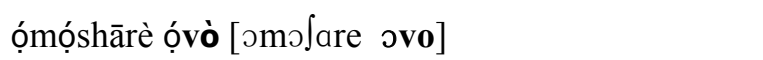 \\
\hline & Une fille & 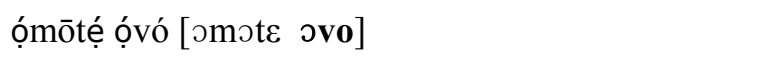 \\
\hline & Un homme & ọ́shārè ọ́vó [つ]are ovo] \\
\hline & Une femme & àyē ọvó [aye ovo] \\
\hline & Une personne & òhwō ọ́vó [ohwo əvo]. Akpofure (op. cit., p. 201) \\
\hline
\end{tabular}

This means that while in French the indefinite article serves as a prefix, in Urhobo it serves as a suffix.

\section{Pluralization of the Indefinite Article}

The plural form of the Urhobo indefinite article is /évó/ as opposed to /ọvó/ as used above. Note that there is a replacement of the singular vowel /o/ [o] with a plural vowel /e/ [e]. Like the French singular indefinite article, the plural French indefinite article also precedes the noun but it does not distinguish between genders.

\begin{tabular}{|c|c|c|}
\hline \multirow[t]{5}{*}{ Example: } & French & Urhobo \\
\hline & Des garçons & éméshārè évó [emefare evo] \\
\hline & Des filles & èmētè évó [emetc evo] \\
\hline & Des hommes & 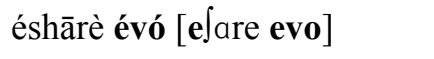 \\
\hline & Des femmes & éyā évó [eya evo] \\
\hline
\end{tabular}




\begin{tabular}{|c|c|c|}
\hline & Des gens & íhwó évó [ihwo evo]. Akpofure (2015, p. 201) \\
\hline \multirow[t]{6}{*}{ Urhobo: } & Singular & Plural \\
\hline & 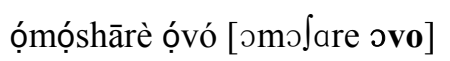 & éméshārè évó [eme〕are evo] \\
\hline & 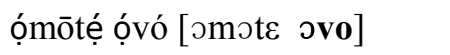 & èmētè évó [emet $\varepsilon$ evo] \\
\hline & ọ́shārè ọ́vó [ə〕are วvo] & éshārè évó [e [are evo] \\
\hline & àyē ọ́vó [aye วvo] & éyā évó [eya evo] \\
\hline & òhwō ọ́vó [ohwo vo] & íhwō évó [ihwo evo] \\
\hline
\end{tabular}

\section{The Partitive Article}

French grammar features partitive articles. Concerning this, Ade Ojo (op. cit., p. 79) says: "The partitive, compressed form of de + definite article (du, de l', de la. Des) meaning some, part of and from is used before concrete nouns that are uncountable or of undetermined quantity to express a certain quantity of something". Alden (1965, p. 200), means the same thing when he says: "The partitive article consists of "de + the definite article agreeing with the noun modified... the partitive article is the plural of the indefinite article (which is omitted in English or expressed by the word some". This notion of some has an equivalent in Urhobo - /évó/. But it is not necessarily used with uncountable nouns. The Urhobo (article) /évó/ [evo] meaning/des/ in French is used with countable nouns as in /èmētè évó/, /éshārè évó/, etc., the singular form being /ọvò/ meaning un/une.

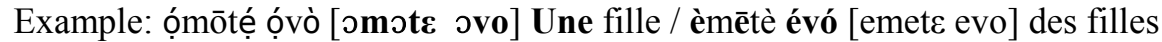

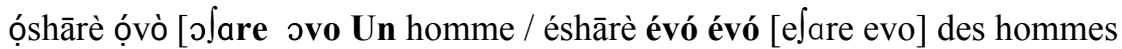

$/ \mathrm{Du} /$ is more closely expressed by the Urhobo article /émé/ [eme], this being the prefix for /émērhà/ meaning /un peu/. "émē" is taken from the Urhobo word "émērhà". It is used for uncountable nouns such as /ámé - eau/, /émú - repas/, /èrhárè - feu/, /ùdí - boisson/, and /oké - temps/.

Example: Bíkó, kè̀ vwe áma ámè [biko keve am ame] S'il te plait, donnes- moi un peu de l'eau.

Kè̀vwe éme émù [kev em emu]- Donnes-moi un peu de repas / Donnes-moi du repas.

Kẹ̀vwe éme érhārè [kєv em erhare] Donnes-moi du feu

Úmūdí je ērò ? [umudi 3 ero] Il reste toujours du boisson?

Mè guōnẹ ómọ ókè [me gwon om ske] Il me faut un peu du temps / Il me faut du temps

With the intransitive verb /aller/, the article + prepositions /a + le/ or /a + les/ result in /au/ or /aux/ as the case may be.

Example: /Je vais à + le marché/Je vais au marché = Mí kpoō ékí.

This translation does not indicate a contraction of article + preposition. (No article is seen to have been used in the Urhobo sentence here.) This sentence indicates vowel elongation. In the Urhobo sentence, /Kpó/ is the verb /to go/ = aller. /ékí/ is the noun. This noun does not have an article. The partitive as well as the tense (present) is expressed in the lengthening of the vowel $/ \mathrm{o} /$.

Example: Mí kpóo... Je vais au...

ékí Marché

Mí kpoō ékí / Je vais au marché

\section{Demonstrative Adjective (Determiners)}

Ade Ojo (op. cit., p. 217) also affirms that the demonstrative adjective helps to show or indicate other words; it points to the noun and agrees with it in number and gender. The demonstrative adjective precedes a 
noun. He notes the simple form of the French demonstrative adjectives or determiners as: $\mathrm{Ce}$, Cet, (masculine), Cette, (feminine) Ces, (plural). Their Urhobo equivalents are as follows: Ce, Cet. = Náná; Cette $=$ Náná; Ces = Náná. These are shown in the following table:

$\begin{array}{llll}\text { Examples: } & \text { Masculine } & \text { Feminine } & \text { Plural } \\ \text { French } & \text { Ce garçon } & \text { Cette fille } & \text { Ces garçons / ces filles } \\ \text { Urhobo } & \text { lọmọ̣shārè náná } & \text { ọmōtẹ́ náná } & \text { éméshārè nana / èmētè náná } \\ \text { French } & \text { Cet homme } & \text { Cette femme } & \text { Ces hommes / ces femmes } \\ \text { Urhobo } & \text { ọ́shārè náná } & \text { àyē náná } & \text { éshārè náná / éyā nana. Akpofure (op. cit., p. 201). }\end{array}$

The following examples show their usage in sentence structures. These sentences are taken from Martinet and Evans et al. (1971, p. 139).

(1) Ce disque, Paul me le donne / ộsēté r ùnè náná, Ípọ́lù vwērọ́ kēvwè.

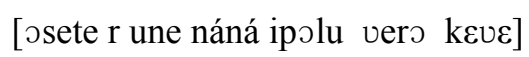

(2) Cette serviette est à vous ? / óriābò nànà, ówēwé yí vwóró? ówēwé yí vw (e) óriābò nánà ?

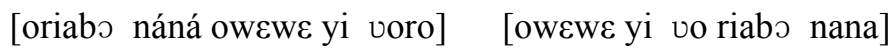

The compound form of the demonstrative adjectives is created by adding the suffix /ci/ to the simple forms.

$$
\text { Ce-ci/cet-ci cette-ci Ces-ci, ces-là }
$$

$\begin{array}{llll}\text { Examples: } & \text { Masculine } & \text { Feminine } & \text { Plural } \\ \text { French } & \text { Ce garçon-ci } & \text { Cette fille-ci } & \text { Ces garçons-ci / ces filles ci } \\ \text { Urhobo } & \text { ọmộshārè náná } & \text { ọmōtẹ́ náná } & \text { éméshārè náná / èmētè náná } \\ \text { French } & \text { Cet homme-ci } & \text { Cette femme-ci } & \text { Ces hommes-ci / ces femmes-ci } \\ \text { Urhobo } & \text { ọ́shārè náná } & \text { àyē náná } & \text { éshārè náná / éyā náná }\end{array}$

The Urhobo demonstrative article "náná" does not really translate the French "ci". For example, in "ómóshārè náná" the "ci" is simply implied. On the other hand, if one says ọ́shārè étinē nà, while it expresses "ci”, the demonstrative adjective náná is thrown off. To retain it one would have to say ọ́shārè náná.

\section{Demonstrative Pronouns}

Ade Ojo (2002, p. 217) as well as Lawless $(2015$, p. 1) affirm that the demonstrative pronoun refers to a noun that has just been mentioned and which we do not want to repeat, so the pronoun is used instead of the noun. Also, according to Lawless (op. cit.), "They must agree with the gender and number of the noun they replace". Lawless explains further and says that "Each of the four demonstrative pronouns can refer to something nearby or far away" but that if one wants to stress one or the other a suffix can be used. Ade Ojo also indicates clearly the French demonstrative pronouns by splitting them into various groups: the neuter, simple and compound forms as follows:
Neuter Forms:
(Masc sing) Ceci (Fem sing) Cela (Masc plu) Ceux-ci /ceux-là
Simple Forms:
(Masc sing) Celui (Fem sing) Celle
(Masc plu) Ceux (Fem plu) Celles
Compound Forms: (Masc sing) Celui-ci, celui-là (Fem sing) Celle-ci, celle-là
(Masc plu) Ceux-ci, ceux-là (Fem plu) Celles-ci, celle-là

In the following table we have paired them with their Urhobo equivalents.

$\begin{array}{llll} & \text { Masculine } & \text { Feminine } & \text { Plural } \\ \text { Fr. } & \text { Ceci } & \text { Cela } & \text { Ceux-ci / ceux-là }\end{array}$




$\begin{array}{llll}\text { Urh. } & \text { ọnāná } & \text { ọ́yēná } & \text { Éyēná } \\ \text { Fr. } & \text { Celui } & \text { Celle } & \text { Ceux / Celles } \\ \text { Urh. } & \text { ó rẹ́ } & \text { ó rẹ } & \text { É ré } \\ \text { Fr. } & \text { Celui-ci } & \text { Celle-là } & \text { Ceux-ci, ceux-là / Celles-ci, celles-là } \\ \text { Urh. } & \text { ọnā rō étínē ná } & \text { óyē rō óbóyī nà } & \text { Énā re étínē nà / Éyé rē óbóyī nà }\end{array}$

As touching the group of pronouns under study, it is noted that whereas French distinguishes between the masculine and feminine genders Urhobo does not. In Urhobo language grammar, the demonstrative pronouns refer to all nouns whether masculine or feminine. Here are some examples.

\section{French}

(1) Ceci est le jour de joie.

(2) Cela est grande

(3) Ceux-ci sont rouges

(4) Ceux-là sont blancs

(5) Celui-ci est mon sac ộná rō étīnè nà ékpō mè [ona ro etin $\varepsilon$ na ekpo $\mathrm{m} \varepsilon$ ]

ọnāná ékpō mé [onana ekpo $\mathrm{m} \varepsilon$ ]

(6) Celle-là est sa serviette ộyé rō óbōyì nà ékpō re ísíkūrù ro yé

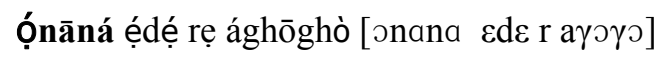

Énānà évwávwārè [enana evavare]

Éyēná éfuāfó [eyena efwafo]

(7) Celles-là sont mes robes Éyēná íwūn mè [eyen iwũ $m \varepsilon$ ]

óyēná rhórò [oyena rhoro], ốyēná ọ́rode [oyena orode]

It had been noted earlier that Urhobo pronoun has no gender distinction but it does distinguish between singular and plural by way of vowel modulation as can also be seen from the above five examples. To serve as examples the following sentences are drawn from Martinet and Evans (1971):

(1) Je ne veux pas celui-ci. Je voudrais celui-là.

Mé guōne ộnà rō étínè nàá. Mé guōne ộyē re óbóyī nà. [me gwon ona ro etine na' '] [me gwon oye ro oboyi na]

(2) Je ne veux pas celle-ci. Je voudrais celle-là.

Mé guōne ộnà rō étínè nàá. Mé guōne ộyē re óbóyī nà. [me gwonona ro etin\& na' '] [me gwonวye ro oboyi na]

(3) Je ne veux pas ceux-ci. Je voudrais ceux-là.

Mé guōne énà re étínè nàá. Mé guōne é re óbóyī nà. [me gwon ena re etine na' '] [me gwon e re oboyi na]

(4) Je ne veux pas celles-ci. Je voudrais celles-là.

Mé guōne énà re étínè nàá. [me gwon ena re etine na' '] Mé guōne éyē re óbóȳ̄ nà. [me gwon eye re oboyi na]

(Celui qui / ọ́ ré), (celui que / ọ ré), (celui de / ọ ré).

Ade Ojo (op. cit.) further explains that: "In principle, the simple forms of the demonstrative pronoun are always followed by the preposition /de/ or any of the relative pronouns: qui, que, à qui, auquel, à laquelle (and their plurals). In Urhobo, this preposition is /re/, /o/ being the demonstrative pronoun. It responds to the question /Ọvọ?/ [əvə] - /Quel?/, /laquelle?/, /lequel?/.

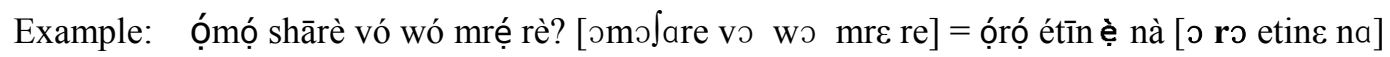
Quel garçon as-tu vue?

Celui-ci. 


$$
\begin{array}{ll}
\text { Oóyēná vwo ? [วyena vo] } & \text { Et celui-là? } \\
\text { Mè mre ọ́yēná à [me mr วyena' '] } & \text { Je n'ai pas vue celui-là. }
\end{array}
$$

For all the prepositions which follow the French demonstrative pronouns, Urhobo has only one form. That is /ọ ré/. It does not distinguish between masculine and feminine. It could be qui, que, à qui, auquel, à laquelle. The following examples are taken from Capelle et Capelle (1970, p. 70).

\section{A. Celui qui/ ọ́ ré :}

i. Il a lu la lettre qui annonce ton arrivée / qui est arrivée hier soir / Celle que tu as reçue.

Ó se óbē rẹ ó vuẹ ōvuẹ̀ rẹe ẹ́chá wē ná rè / rẹ ọ́ rhērè vwẹ óvwōvwó ódēyè / ọ́ ré ótēwe óbò.

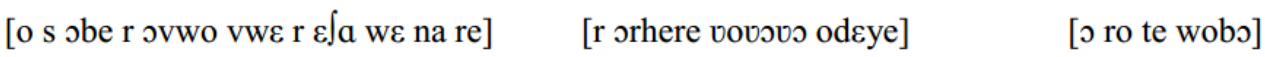

ii. J'ai vu le film qui passe au Logos, qui a gagné le Grand Prix à Cannes. Celui que Pierre n'a pas aimé.
Mé mrẹ ūghé rẹ é djēphià vwẹ īLógōsi. o ọ rẹ ó mu úkō ródē nà $\quad$ rẹ íPierre guònọ́ rēè

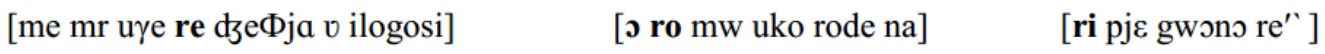

\section{B. Celui que / ọ́ ré}

i. Ceux qui sont venus me voir habitent à côté d'ici

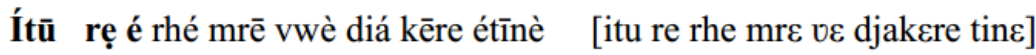

ii. Celles que mon père a reçues sont trop chères.

Íri í te ōsémẹ óbō ghàré nò [ir i to scm obo yare no]

C. Celui de / ố ré

i. J'ai pris mon parapluie Moi, j'ai pris celui de ton oncle

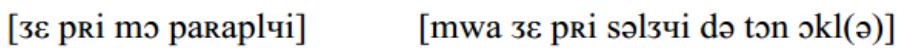

Mē réyẹ éhārhá mē rè Ómévwè, mē réyẹ ộ rẹ óniōvó rẹ ộsēwè

[me rey eharha $\mathrm{m} \varepsilon$ re] [omeve me rey oro njovo ro $\mathrm{s} \varepsilon \mathrm{w} \varepsilon]$

ii. J'ai pris mes livres Moi, j'ai pris ceux de ma sœur

Mē réyẹ ébé mẹe rè. $\quad$ Ómēvwè, mē réyẹ é rẹ óniōvó mẹ̀

[me rey sbe mere] [omeve me rey e r onjovo $\mathrm{m} \varepsilon$ ]

J'ai pris mes photos Moi, j'ai pris celles de mes parents.

Mē réyẹ íhōhò mé rè. OŌmèvwè, mē réyẹ ē re ósémè vẹ ónīmè

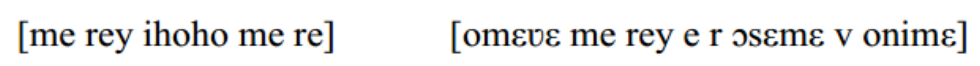




\section{Phonological Processes}

Urhobo phonological processes which feature in this work include: (1) assimilation and (2) elision. One of the rules in Urhobo grammar stresses that though all letters in the word are written but not all of them should be pronounced. This means that like the French language, Urhobo words are not pronounced as written.

\section{Assimilation}

Akpofure (2015) also discussed assimilation. She quoted Aziza (2007) as saying that: "Assimilation is a process whereby a segment takes on some or all of the features of a neighbouring segment... In Urhobo, where there are contiguous vowels, and one does not delete, assimilation occurs..." (p. 288). The following sentences indicate the points at which assimilation occurs in Urhobo articulation of these words. The sentences in French used in the following examples are taken from Martinet and Evans (1971, p. 139):

Example (1) Ce disque, Paul me le donne /ộsēté r ùnè náná, Ípọ́lù vwērọ́ kēvwè.

[osete rune nana ipolu vero $\mathrm{k} \varepsilon v \varepsilon$ ]

In this sentence the vowel $[\mathrm{u}]$ assimilates the vowel /e/. This compresses the two words /rẹ/ (de) and /une/ (song) into one word /rune/, modulating the sound yet retaining the meaning.

Example (2) Ces disques, Paul me les donne /ísēté rẹ iné nānà, Ípólù vwāyé kēvwè.

[isete rine nana, ipslu vaye $\mathrm{k} \varepsilon v \varepsilon$ ]

In this sequence what happens to /re une/ above also happens to /re ine/. Actually, this assimilation occurs at the point of speech articulation, which is why /re ine/ is transcribed as [rine]. This calls to mind the fact that the last letters of French words are not usually pronounced. While this can be said to be a similarity, it should be noted that the unpronounced letters in French are not necessarily assimilated. They are just not pronounced in speech articulation.

Example (3) Cette serviette est à vous? óriābò nànà, ọ́wẹ́? [oriabっ nana $ə w \varepsilon]$ óriābò nànà, ówēwẹ́ yí vwórò? Ówēwé yî vw(e) óriābò nànà?

[oriabo nana owewe yi voro] [owew\& yi $v$ oriabo nana]

In this sentence, /vwẹ óriābò / also indicates assimilation when it is transcribed as [v oriabo]

Example (4) Je ne veux pas celui-ci. Je voudrais celui-là.

Mé guōno ộnà rō étínè nàá. Óyé re óbóyī nà mé rhá guōnò

[me gwon ona ro etine na' '] [oye ro oboyi na me rha gwonว]

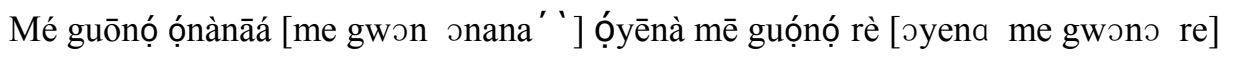

/guōno ộnānà/ [gwon วnana] as well as /guōno ộyēnà/ [gwวnəyena] are also points of assimilation.

\section{Elision}

It had been noted earlier in this work, that at the level of the definite article, vowel elision is observed when two vowels come together as in /la église - l'église/, /la école - l'école/, or when a vowel comes in contact with the aspirate /h/, as in /le hôpital - l'hôpital/. It is not so in Urhobo. Both vowels are left in place in written form but elision takes place during speech articulation.

\section{Conclusion}

So far this work has treated various forms of articles as well as demonstrative structures. To conclude, we present a summary of the findings of this study.

(1) Unlike the French article, the Urhobo article has no parts other than one- "Nà". It is used to express 
the definite as well as the indefinite article. The Urhobo article "na" does not come before the noun. It comes after it;

(2) In Urhobo neither the article /nà/ nor the noun takes an /s/ to form the plural as with the French plural form. The initial vowel of the Urhobo noun modulates to another vowel according to the nature of the vowel in question. Ex: ọ́mọ́ (sing) = Émọ́ (plural);

(3) Quite like the French plural form, the Urhobo plural form does not distinguish between the masculine and the feminine gender;

(4) The Urhobo indefinite article /óvó/ does not indicate the gender of the noun whereas the French indefinite article /un/ and /une/ do so. Like the definite article, the indefinite article /ọ́vọ́/ does not precede the noun. It comes after it;

(5) The partitive article /du/ does not exist in Urhobo. It has an equivalent which is the prefix of an Urhobo adjective /émērhà/ meaning /un peu/, émé being the prefix. Thus we have /kēvwe éme émù/ - Donnes - moi du repas. Literally, it translates as /Donnes-moi un peu de repas/;

(6) While in French the partitive article /au/ is got from article + preposition, in Urhobo, it is a process of vowel elongation that creates the equivalent of this process, hence the partitive article /au/ and /aux/ would seem not to exist in Urhobo;

(7) In French the demonstrative adjective comes before the noun. In Urhobo it comes after the noun. French demonstrative adjectives indicate genders; Urhobo demonstrative adjectives do not indicate genders;

(8) French demonstrative pronouns indicate genders. Urhobo demonstrative pronouns do not indicate genders.

\section{General Differences as Observed in This Study}

\section{The Use of the Plural "Vous"}

The French pronoun /vous/ calls into play the Urhobo pronoun /òvwá/. Apart from the generic plural form of /vous/, Coffey (2014, pp. 2-3) explains that "vous" is commonly used in formal or polite speech, generally, when speaking to older persons, or superiors as in a hierarchy for instance, or to unfamiliar persons. "Vous" can also be used to express displeasure or contempt. This implies that the French pronoun /vous/ is used in various contexts. The Urhobo plural pronoun /òvwá/ simply refers to the generic plural form as in "Òvwá íhwō mè..."/“vous mes gens", “òvwá émōnà”/Vous les enfants/; "òvwá íhwó re ínāíírià...Óghēné cha ōvwá ūkò!/Vous les nigérians!... Que Dieu vous aide!"

\section{Negation}

It was also noted that whereas in French negation was expressed with two words "ne...pas" with the verb in between; Urhobo simply adds another vowel to the end vowel as in /Mè guōnò réè/ [me gwonə re' '] Je ne veux pas. Note that the additional vowel /e/ is transcribed with an extra tone mark. /Ó diẹ ómēvwéè/ [o die omeve' '] Ce n'est pas moi; /Mē chà réè/ [me fa re' '] Je ne vais pas manger.

\section{Voudrais}

Je voudrais celui-là. From the verb "vouloir" - to want. Urhobo does not provide a direct word to word equivalence of the conditional tense used in this sentence. For example:

Óyēnà mé rhà guōnò/J'aurais voulu celui-là. In this example, “j'aurais voulu” translates "mé rhà guōnò”. Meanwhile, "aurais" is the past conditional mood of the verb "avoir". But "avoir" does not feature in the 
French sentence "Je voudrais celui-là". Urhobo amplifies the sentence in order to provide an acceptable translation, hence /je voudrais/ translates into "me rha guono". Why not "Mé rhá guōno óyēnà" "Je voudrais celui-là ".

\section{iLogosi}

The vowel /i/ comes in here because, according to Aziza, cited in Akpofure (2015, p. 208), "That is a syllable structure constraint in Urhobo". It is common therefore to hear Urhobo people say: /ígógōnó/ instead of /gógōnó/ - seau. /íMíshēlù/ - Michel, /íPier/ - Pierre. As touching a noun that already begins with a vowel as in /ámé/ - /eau/, /ódjá/ - /savon/, /áphiá/ - /couteau/, Urhobo has no problem. It was also noted that these initial vowels are most commonly used with borrowed words such as: /égānásè or égālásè - glass/, /ífōtó - photo/, /ótásò - tasse/.

\section{References}

Ade Ojo, S. (2005). A comprehensive revision handbook of French grammar. Ibadan: Signal Educational Services Limited.

Akpofure, C. E. (2015). Une étude comparée des systèmes phonologiques du français et de l'urhobo (A comparative study of French and Urhobo phonological systems) (A thesis in the Department of Modern Languages, submitted to the Faculty of Arts in partial fulfilment of the requirements for the Degree of Doctor of Philosophy of Ambrose Alli University, Ekpoma).

Alden, D. W. (1965). Cortina Collins, French in twenty lessons. London and Glasgow: Collins.

Aziza, R. O. (1997). Urhobo tone system (A thesis in the Department of Linguistics and African Languages, submitted to the Faculty of Arts in partial fulfilment of the requirements for the Degree of Doctor of Philosophy of the University of Ibadan).

Aziza, R. O. (2007). Urhobo phonology. In Basic linguistics for Nigerian languages teacher. Port Harcourt: Linguistics Association of Nigeria in collaboration with M \& J Grand Orbit Communications Limited.

Capelle, J., \& Capelle, G. (1970). La France En Direct 2. Paris: Librairie Hachette.

Coffey, N. (2014). When do I use /tu/ and when do Iuse /vous/? Retrieved from http://www.frenchlinguistics.co.uk/grammar/tu_and_vous.shtml

Dale, J. B., \& Dale, M. L. (1956). Cours Elémentaire de Français. Boston: D. C. Heath and Company.

Hornby, A. S. (2000). Oxford advanced learners dictionary. Oxford: Oxford University Press.

Larousse. (2004). Conjugaison. Espagne: Liberduplex.

Lawless, L. K. (2015). French demonstrative pronouns-Pronoms démonstratifs. Retrieved from http://french.about.com/od/grammar/a/pronouns_demonstrative.htm

Martinet, A., Evans, L., Gimson, A. C., Quirk, R., Lehmann, A. G., Marling, J., \& Bellancourt, M. (1971). A French course handbook. Linguaphone Institute Limited. 207 Regent Street, London WIR 8AU.

Mauger, G. (1968). Cours De Langue et De Civilisation Françaises II. Paris: Librairie Hachette Paris.

Mazet, V. (2015). French definite articles. Retrieved from http://www.dummies.com/how-to/content/ french-definite-articles.html

Odiemo, R. T. (2014). Urhobo people. Retrieved from https://en.wikipedia.org/wiki/Urhobo_people

Robert, P., Rey, A., Rev-Debove, J., Cottez, H., Lafite, Y., Léotard, L., \& Penchenat, G. (1980). Micro Robert. Paris, France: Le Robert.

Trueman, P. (2015). Article (grammar). Retrieved from https://en.wikipedia.org/wiki/Article_(grammar)

Ukere, A. O. (1984). English-Urhobo dictionary. Benin-City: Ilupeju Press.

Yusuf, O. (2007). Basic linguistics for Nigerian languages teacher. Port Harcourt, Linguistics Association of Nigeria in collaboration with M \& J Grand Orbit Communications Limited.

Zuraw, K. (2014). Optimality theory in linguistics. Retrieved from http://www.linguistics.ucla.edu/people/zuraw/dnldpprs/OTHBTNN2e.pdf 